\title{
SUMMARY OF ACCOMPLISHMENTS OF AAAS FELLOWSHIP PROGRAM
}

Grant No.: ER61974

In 1995 the ASHG/DOE AAAS Congressional Fellow Program was established to initiate a dialogue between the professional genetics community and federal policy makers. The originally stated purpose of the ASHG AAAS program was to raise the awareness of Congressional committee and staff members on the impact that the delivery of genetics services as a part of health care will have on Americans. The program has been instrumental in drafting new legislation to keep up with the ethical issues evolving from this explosion of genetic information.

Four fellows have served since the inception of the ASHG/DOE Congressional Fellowship Program, one year each in both houses of Congress and the fifth will serve for the remainder of 2001. In the $105^{\text {th }}$ and $106^{\text {th }}$ Congresses several bills were introduced on health issues related to genetics but none received final action. New bills are being planned for the $107^{\text {th }}$. Even though the future of these bills remains uncertain at this time, it has become obvious that Congress is beginning to see the necessity of developing federal legislation to complement the leaps in biotechnology we are now experiencing. Newly elected members of Congress as well as the Congressional staff members need to be educated on a continuing basis about how the field of human genetics impacts society.

Now that the human genome mapping effort is nearing completion, it has become even more crucial to establish policies regarding human medical genetics practice. Since the beginning of the program, many gains have been made towards understanding genetics and the development of federal policy particularly by government agencies. Staff on Capitol Hill have been retained especially to study questions on genetic testing, discrimination by insurance carriers and employers, access for all with respect to genetic services delivery and privacy for everyone touched by the consequences of the new technologies. It is for these reasons that ASHG feels the program has been valuable.

Specifically, the fellows who already have served have reported on the following activities:

1996

Maimon M. Cohen, PhD, FACMG, prepared briefings and talking points for Senator Wellstone's (S-MN) office on the FDA Reform Bill, the Medical Devices Bill, Confidentiality of Medical Records Act, Genetic Privacy and Nondiscrimination Act, Health Insurance Reform Act and the NIH Revitalization Act and participated in detailed discussions with the FDA on the Senator's behalf on programs for nonFDA-approved drugs in the treatment of life-threatening conditions. 


\section{DISCLAIMER}

This report was prepared as an account of work sponsored by an agency of the United States Government. Neither the United States Government nor any agency thereof, nor any of their employees, makes any warranty, express or implied, or assumes any legal liability or responsibility for the accuracy, completeness, or usefulness of any information, apparatus, product, or process disclosed, or represents that its use would not infringe privately owned rights. Reference berein to any specific commercial produet, process, or service by trade name, trademark, manufacturer, or otherwise does not necessarily constitute or imply its endorsement, recommendation, or favoring by the United States Government or any agency thereof. The views and opinions of authors expressed herein do not necessarily state or reflect those of the United States Government or any agency thereof. 


\section{DISCLAIMER}

Portions of this document may be illegible in electronic image products. Images are produced from the best available original document. 
1997

Mary Z. Pelias, PhD, JD, worked with the staff in the office of Senator Pete Domenici (R-NM). Pelias had the opportunity to participate in the crafting of the most comprehensive bill on genetic confidentiality and nondiscrimination seen to date. This bill was a close copy of model legislation that had been published in 1995 as a framework for both federal and state legislation. The Domenici bill of 1996 was broad in scope, a bit shakey with respect to legal theory, and decidedly negative in tone with respect to the genetics research interests. However, the bill was a sincere effort to protect the rights and interests of the individual. It was rewritten with the following goals: to strengthen the rights of individuals through a thorough procedure for informed consent, to respect the interests of the research community, and to preclude requests or requirements of personal genetic information as a condition of employment or health insurance coverage.

\section{9}

Carol L. Greene, MD, FACMG, worked for one year on the staff of the Public Health Subcommittee for Senator Edward Kennedy. Senator Kennedy was the ranking minority member of the Health, Education, Labor and Pensions (HELP) Committee. He was also the ranking minority member for HELP's Public Health Subcommittee which has authority over most activities of HHS including activities of NIH, CDC, HRSA, AHCPR, FDA, SAMHSA and many activities of HCFA. As a result, the committee staff was involved in virtually every health and medical science activity in the Senate and was a focal point for interaction with the House of Representatives and with the White House.

Dr. Greene contributed significantly to redrafting the Senate Democratic genetic discrimination proposal and on S. 1981, The Genetics and Public Health Services Act. This Act amends the Public Health Service Act to establish, expand and maintain resources and expertise needed for safe and effective use of genetic information and technology in state and local public health programs and support essential applied research and systems development to translate new and emerging genetic information into practical public health strategies.

Most of Dr. Greene's time was devoted to a wide variety of issues of general importance to public health. She interacted with many federal and state agencies, congressional offices and committees and a wide range of lobbyists and advocacy groups in order to accomplish the work of the committee.

\section{0}

Judith L. Benkendorf, MS, CGC, participated in the drafting of numerous bills in the second session of the $106^{\text {th }}$ Congress. Titles of the bills were:

HR4365, the Children's Health Act of 2000 S 1809/HR 4920, the Developmental Disabilities Assistance and Bill of Rights Act (DDA) 
S 1980/HR 3520, the Health Care Fairness Act

HR 4368, the Breast and Cervical Cancer Treatment Act

HR 1795, the National Institute of Biomedical Imaging and Engineering

Establishment Act

HR 3514, the Chimpanzee Health Improvement, Maintenance and Protection

(CHIMP) Act

HR 4281, the Interagency Coordinating Committee on Validation of Alternative

Test Methods (ICCVAM) Authorization Act of 2000

HR 2498, the Public Health Improvement Act of 2000

H. Res. 163, Expressing the Sense of the House of Representatives with

Respect to Post-Partum Depression

H. Con. Res. 271, Expressing the Support of Congress of Activities to Increase

Public Awareness of Multiple Sclerosis

She noted at the conclusion of her fellowship year that the following initiatives should be tracked in the formative stages of the $107^{\text {th }}$ Congress:

- Sustaining federal funding for research;

- Possible changes to the guidelines for the use of animals in research;

- Further guidelines on the use of human biological materials;

- Changes to federal funding guidelines for research involving human embryonic stem cells and fetal tissue;

- Human research subject protections issues including IRB reform, informed consent issues, managing investigator and institutional conflicts of interest, and new international research guidelines;

- Patenting of genes, with continued discussions of definitions;

- Establishing federal oversight and regulation for genetic tests;

- Revisiting the Bayh-Dole Act of 1980 , which promotes technology transfer by encouraging federally funded researchers to patent inventions and grant licenses on these patents;

- The House Commerce Committee oversight investigation of human gene transfer research was "ongoing" at the close of the $106^{\text {th }}$ Congress. It is likely to evolve into an investigation of the Federal infrastructure for human subjects' research oversight.

- Impact on the definition of "orphan" drugs of the new generation of pharmaceuticals being developed for target populations based on genomic data; 
- Safety of genetically modified foods and use of GMOs in agriculture.

Issues of concern to the clinical genetics community will include:

- Genetic non-discrimination in health insurance and employment;

- Medical records privacy;

- Reauthorization of the Health Professions Act in 2002, which could be amended to make available money for training genetics professionals.

2001

Diane Baker, MS, is working with the staff in the office of Senator Harry Reid (DNV).

When the program began in 1995 there were few individuals in the genetics community conversant with the federal mechanisms for policy development and implementation. Now that four fellows have completed their years of service, the ASHG feels that there is a resource for advising Congressional staff about proposed legislation and the Society about the feasibility of developing new inroads in federal law. 